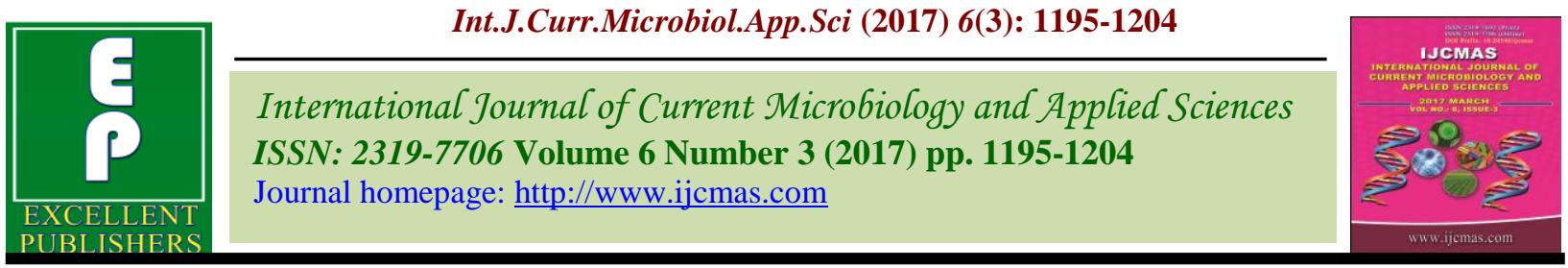

Original Research Article

https://doi.org/10.20546/ijcmas.2017.603.139

\title{
Exploration of Algal Varieties from Panikhaiti Area of Guwahati using Winogradsky Column
}

\author{
Sushma Gurumayum* and Sushree Sangita Senapati \\ Department of Microbiology, College of Allied Health Sciences, \\ Assam down town University, Panikhaiti, Guwahati - 781026, Assam, India \\ *Corresponding author
}

\section{A B S T R A C T}

\section{Keywords}

Winogradsky column; Micro algae; Soil; Panikhaiti.

Article Info

Accepted: 20 February 2017 Available Online: 10 March 2017
An attempt has been made to explore different types of algae from Panikhaiti area of Guwahati, Assam using Winogradsky column. In order to prepare Winogradsy column, soil and water samples were collected from different locations. A transparent, clear plastic bottle was taken and filled with $500 \mathrm{~g}$ of soil and over layered with $500 \mathrm{ml}$ of water sample. The columns were enriched with different carbon and nitrogen supplements. They were covered with plastic sheets and few holes were punctured on them. These were incubated at room temperature $\left( \pm 28^{\circ} \mathrm{C}\right)$ in presence of sunlight. One column was kept covered with dark paper and kept in dark as control. Observations were made weekly, for development of algal growth and microbial communities over a period of 12 months. A gradual change in colour of column and also on the water layer was observed over the course of incubation period. The columns started showing stratified micro ecosystems with an oxic top layer and anoxic sub-surface layers. Algal growth prominently appeared in all the columns. The algal specimens belonged to 18 genera which included members of class Cyanophyceae, Zygnematophyceae, Ulvophyceae, Chlorophyceae, Bacillariophyceae and Euglenoidea.

\section{Introduction}

Algae are found in varied habitats ranging from wetlands, water bodies and moist soil of forest areas. Algae play important role in ecosystem as primary producers and a lot of industrially significant products have been developed using them. Nowadays, algae are also desirable entities for study of carbon sequestration. Thus, there is a requirement to study and document the varieties of algae occurring in various ecological niches and specific geographical areas. Panikhaiti village is located in Chandrapur Tehsil of Kamrup Metropolitan district in Assam, India. It is situated $15 \mathrm{~km}$ away from district headquarter Chandrapur. Chandrapur is the sub-district headquarter of Panikhaiti village. The total geographical area of village is 304.74 hectares. Panikhaiti has a total population of 3,817 . Guwahati is nearest town to Panikhaiti which is approximately $15 \mathrm{~km}$ away. The present study covers some of the village area as well as some of the surrounding forest area. In this study, an attempt has been made to gather information about the algal varieties in these locations. This will add to the pool of existing information about algae diversity present in Assam. Till now there is no work on detailed investigation of algal diversity in Panikhaiti area of Guwahati, Assam. 


\section{Materials and Methods}

The study was conducted for a year from August, 2015 to Aug, 2016. Water and soil samples were collected from different areas of Panikhaiti region, Guwahati. Using these soil samples, Winogradsky columns were prepared. In each of the columns, the soil was supplemented with different carbon and nitrogen sources. $500 \mathrm{gm}$ of soil mixed with these supplements were overlayered with water sample. These columns were covered with transparent plastic sheets with holes punched in them and incubated at room temperature in presence of sunlight. Observations were recorded after every seven days. Samples of algal growth from: a) upper water layer, b) biofilm on walls of the column and c) surface of soil in the column were collected. Wet mounts of algal samples were prepared and observed under bright field light microscope.

\section{Results and Discussion}

Changes were observed in the Winogradsky column around $7^{\text {th }}$ day of incubation. Initially, the growth of algae was seen in the upper water layer as well as on the sides of the column as a biofilm. As the number of incubation days increased, layer of growth was also seen on surface of soil in the columns. Figure 1 shows the different columns with algal growth in them. Along with the algal growth, the underlying layers of soil also developed different hues of colours showing growth of different groups of bacteria.

The algal specimens observed in the columns belonged to 18 genera which included members of class Cyanophyceae, Zygnematophyceae, Ulvophyceaea, Chlorophyceae, Bacillariophyceae and Euglenoidea (Table 1).
Morpho-taxonomic descriptions of the different varieties of algae studied from these Winogradsky columns are given as follows.

\section{Chroococcus}

Kingdom: Bacteria

Phylum: Cyanobacteria

Class: Cyanophyceae

Order: Chroococcales

Family: Chroococcaceae

Genus: Chroococcus

Chroococcus is a kind of Cyanobacteria found in freshwater. It is unicellular blue green algae. Microscopic colonies are found within an external sheath. They are usually found in colonies inside a transparent protective covering sheath which contains photosynthetic pigments. It inhabits underwater environments like sludge of lake and river bottoms. For photosynthesis, the algae use an extensive quantity of atmospheric carbon creating free oxygen in the atmosphere.

\section{Oscillatoria}

Kingdom: Bacteria

Phylum: Cyanobacteria

Class: Cyanophyceae

Order: Nostocales

Family: Oscillatoriaceae

Genus: Oscillatoria

Oscillatoria is a filamentous blue-green or brown-green cyanobacterium. It is named after the oscillation in its movement. It reproduces by fragmentation. It can form long filaments of cells which can break into fragments called hormogonia. The hormogonia can grow into a new, longer filament. Each filament consists of trichome which is made up of rows of cells and the tip of the trichome oscillates like a pendulum. 
This gives the filaments easier mobility in all directions. It is also able to fix nitrogen.

\section{Phormidium}

Kingdom: Bacteria

Phylum: Cyanobacteria

Class: Cyanophyceae

Order: Oscillatoriales

Family: Phormidiaceae

Genus: Phormidium

It is unbranched and occurs usually in fine, smooth and layered filaments. Filaments are short cylindrical cells in a fine sheath and glide within the sheath. Sheaths are tube-like, firm, colourless, joined to the trichomes, opened at the ends, containing always only one trichome. Trichomes are isopolar, straight, coiled, usually 2-12 $\mu \mathrm{m}$ wide, uniserial, unbranched, composed of cylindrical up to slightly barrel-shaped cells, screw-like twisted towards the ends, motile within and out of sheaths. End cells are tapered, with a calyptra on the terminal cell. Tapering may extend several cells from the end. Organelles absent from the cells, but vesicles are common. They form mats which may be dark brown, green, purple or bluegreen. They can survive in streams as well as rivers.

\section{Lyngbya}

Kingdom: Bacteria

Phylum: Cyanobacteria

Order: Oscillatoriales

Genus: Lyngbya

The organisms are filamentous. They share the entire range of cellular types with oscillatoria. They also produce a distinct and persistent sheath. The sheath is thin and extends beyond the terminal cell of the trichome. The trichome diameters range from $1 \mu \mathrm{m}$ to about $80 \mu \mathrm{m}$. Trichomes are usually nonmotile within the sheath.

\section{Anabaena}

Kingdom: Bacteria

Phylum: Cyanobacteria

Class: Hormogoneae

Order: Nostocales

Family: Nostocaceae

Genus: Anabaena

Anabaena is a filamentous cyanobacteria and exists as plankton. Cells are attached to form unbranched filaments which may appear randomly twisted and coiled or entangled with numerous other filaments. Vegetative cells may be spherical to oblong with granular contents and conspicuous, refractive pseudovacuoles. They fix nitrogen. They show symbiotic relationships with certain plants. They form heterocysts which convert nitrogen into ammonia. Certain species of Anabaena have been used as effective natural fertilizer and found to be productive on rice paddy fields.

\section{Microcoleus}

Kingdom: Eubacteria

Phylum: Cyanobacteria

Class: Cyanophyceae

Order: Oscillatoriales

Family: Microcoleaceae

Genus: Microcoleus

The organism is a terrestrial species which has filaments and are often in an interwoven mat of densely entangled trichomes in one sheath. Trichomes are found arranged parallelly or rope-like. Sometimes only one trichome in terminal branches is present which is known as pseudo-branching, sheath is colorless, diffluent, varying in thickness, not lamellated, with rough with uneven surface. Trichomes attenuate at the ends. End cells are capitate, mainly with calyptras, bluntly-rounded, conical, hemispherical or obtuse-conical. Trichomes are pale blue- 
green, dirty green or olive-green, long, not constricted at cross-walls.

\section{Pseudanabaena}

Kingdom: Eubacteria

Phylum: Cyanobacteria

Class: Cyanophyceae

Order: Synechococcales

Family: Pseudanabaenaceae

Genus: Pseudanabaena

Pseudanabaena species are filamentous bloom-forming cyanobacteria. The organisms are unicellular, colonial, or filamentous bacteria that conduct photosynthesis using chlorophyll a. Pseudanabaena species are nonheterocystous cyanobacteria. They are characterized by simple trichomes with a width less than $4 \mu \mathrm{m}$. The cells are longer than wide, possess parietal thylakoids, contain polar gas vesicles and the cross walls are conspicuously constricted. Most cultured strains reveal gliding motility and some are capable of anaerobic $\mathrm{N}_{2}$ fixation. Pseudanabaena spp. is a dominant group of organisms found in dense water blooms.

\section{Mesotaenium}

Kingdom: Plantae

Phylum: Charophyta

Class: Zygnematophyceae

Order: Zygnematales

Family: Mesotaeniaceae

Genus: Mesotaenium

Mesotaenium is a unicellular, short, straight, cylindrical, solitary alga within common gelatinous matrix with simple or layered structure. Cells size vary from10-123 $\mu \mathrm{m}$ long, straight or slightly curved, long or short cylindric, with broadly rounded ends. Cell has one or two chloroplasts with 1 or 2 pyrenoids. Cell wall is two-layered. Asexual reproduction is usually by transverse cell division and sexual reproduction by conjugation. Zygote within the conjugation tube extends into both gametangia. Mature zygospores spherical to quadrate, or polygonal, with smooth or papillate outer surface and smooth mesospore wall layer. Mesotaenium resides mostly often as small gelatinous masses among mosses, or on moist soil or rocks; occasioanlly in acidic, oligotrophic, aquatic habitats or in acid bogs. Each cell has a single axial, plate-like chloroplast with one or several pyrenoids. The cells are solitary or aggregated within common mucilage to form irregular colonies.

\section{Spirogyra}

Kingdom: Plantae

Phylum: Charophyta

Class: Zygnematophyceae

Order: Zygnematales

Family: Zygnemataceae

Genus: Spirogyra

Spirogyra is also known as water silk, mermaid's tresses, and blanket weed. They are filamentous green algae with helical or spiral arrangement of the chloroplast. It is commonly found in fresh water. In spring, Spirogyra grows under water, but when there is enough sunlight and warmth they produce large amounts of oxygen, adhering as bubbles between the tangled filaments. Spirogyra measures approximately $10 \mu \mathrm{m}$ to $100 \mu \mathrm{m}$ in width and may grow to several centimeters in length. It develops slimy, filamentous green masses. The filamentous masses form slimy green mats on the surface. Spirogyra can reproduce both sexually and asexually. In vegetative reproduction, fragmentation takes place, and Spirogyra simply undergoes the intercalary mitosis to form new filaments.

\section{Ulothrix}

Domain: Eukaryota

Kingdom: Protista 
Phylum: Chlorophyta

Class: Ulvophyceae

Order: Ulotrichales

Family: Ulotrichaceae

Genus: Ulothrix

Ulothrix is eukaryotic, unicellular filamentous green algae. They inhabit in fresh and marine water. They can also survive in the low temperatures of spring. The cells are normally as broad as they are long. They become attached to surfaces by a modified holdfast cell. Reproduction is vegetative. It consists of unbranched, uniseriate filaments arranged end to end. They are barrel-shaped or cylindrical. The apical cell is rounded at its terminal end whereas the basal cell is elongated. It is also called the basal holdfast, which attaches the filament to the substratum. The cell wall is composed of propectin and cellulose. Each cell has a single girdle-like and parietal chloroplast and pyrenoids are present in each chloroplast.

\section{Chlamydomonas}

Domain: Eukaryota

Kingdom: Plantae

Division: Chlorophyta

Class: Chlorophyceae

Order: Chlamydomonadales

Family: Chlamydomonadaceae

Genus: Chlamydomonas

Species of this genus are found in a wide variety of habitats. When observed under microscope, they appear as small, ellipticaloval cells. They are biflagellate, with two whip-like flagella. A tiny red eyespot at the base of the flagella is a characteristic feature of this alga. There is presence of single large cup-shaped chloroplast.

\section{Chlorella}

Domain: Eukaryota

Kingdom: Viridiplantae
Division: Chlorophyta

Class: Trebouxiophyceae

Order: Chlorellales

Family: Chlorellaceae

Genus: Chlorella

Chlorella is single-cell green algae. It is spherical and 2 to $10 \mu \mathrm{m}$ in diameter, without flagella. It contains the green photosynthetic pigments chlorophyll-a and chlorophyll-b in its chloroplast. It multiplies rapidly through photosynthesis. It requires carbon dioxide, water, sunlight, and a small amount of minerals for its reproduction.

\section{Haematococcus}

Domain: Eukaryota

Kingdom: Viridiplantae

Division: Chlorophyta

Class: Chlorophyceae

Order: Chlamydomonadales

Family: Haematococcaceae

Genus: Haematococcus

Haematococcus are solitary, ovoid to ellipsoidal, with broadly rounded ends. Its size ranges from 5-25 $\mu \mathrm{m}$. They can grow in $4-9 \%$ of moisture. They have 2 equal flagella. Chloroplasts are more or less cup-shaped, sometimes reticulate. It is green in colour but cells often appear as orange or reddish due to extraplastidial carotenoid. Nucleus is present in the central area.

\section{Oedogonium}

Kingdom: Plantae

Division: Chlorophyta

Class: Chlorophyceae

Order: Oedogoniales

Genus: Oedogonium

Oedogonium is found in fresh water like pools, ponds, lakes etc. The thalloid plant body is green, multicellular and filamentous. 
The filaments are unbranched and cells of each filament are attached end to end and form uniseriate row. The filament is differentiated into three types of cells which include basal cell, apical cell and middle cells. Basal Cell is the lowermost cell of the filament. The cell is generally colourless, which performs the function of fixation to the substratum and called holdfast. The topmost cell of the filament is apical cell. The cell is usually rounded towards apical side and green in colour. All the cells in between basal and apical cells are similar. Cells have reticulate chloroplasts. Asexual reproduction takes place by multi- flagellate zoospore. Sexual reproduction is advanced oogamous type. The female gamete is known as ovum and the male gamete is known as antherozoids. The zygote undergoes meiotic division and produces four zoospores.

\section{Gonium}

Domain: Eukaryota

Kingdom: Plantae

Division: Chlorophyta

Class: Chlorophyceae

Order: Volvocales

Family: Goniaceae

Genus: Gonium

Cells are ovoid with a single cup-shaped chloroplast containing one pyrenoid. Each cell has two cilia, contractile vacuoles at the base of the cilia, and an eyespot. They are mostly found in freshwater like pools and ponds. Asexual reproduction is carried out by a formation of 2-4 zoospores in each cell and sexual reproduction is isogamous, by a fusion of biciliate zoogametes. The type of nutrition is phototrophic or chemo or photoorganotrophic.

Table.1 List of algae species under different groups in the present study

\begin{tabular}{|l|l|l|}
\hline Sl.No. & Group & Genus \\
\hline 1 & Cyanophyceae & a) Chroococcus, \\
& & b) Oscillatoria, \\
& & c) Phormidium, \\
& & d) Lyngbya, \\
& & e) Anabaena \\
& & f) Microcoleus \\
& & g) Pseudanabaena \\
\hline 2 & Zygnematophyceae & a) Mesotaenium, \\
& & b) Sprigyra \\
\hline 3 & Ulvophyceaea & a) Ulothrix \\
\hline 4 & Chlorophyceae & a) Chlamydomonas, \\
& & b) Chlorella, \\
& & c) Haematococcus \\
& & d) Oedogonium \\
& & e) Gonium \\
\hline 5 & Bacillariophyceae & a) Pinnularia, \\
& & b) Navicula \\
\hline 6 & Euglenoidea & a) Euglena \\
\hline
\end{tabular}


Fig.1 (1a) Chroococcus, (1b) Oscillatoria, (1c) Phormidium, (1d) Lyngbya, (1e) Anabaena, (1f) Microcoleus, (1g) Pseuanabaena (2a) Mesotaenium, (2b) Sprigyra, (3a) Ulothrix, (4a) Chlamydomonas, (4b) Chlorella, (4c) Haematococcus, (4d) Oedogonium, (4e) Gonium, (5a) Pinnularia, (5b) Navicula, (7a) Euglena

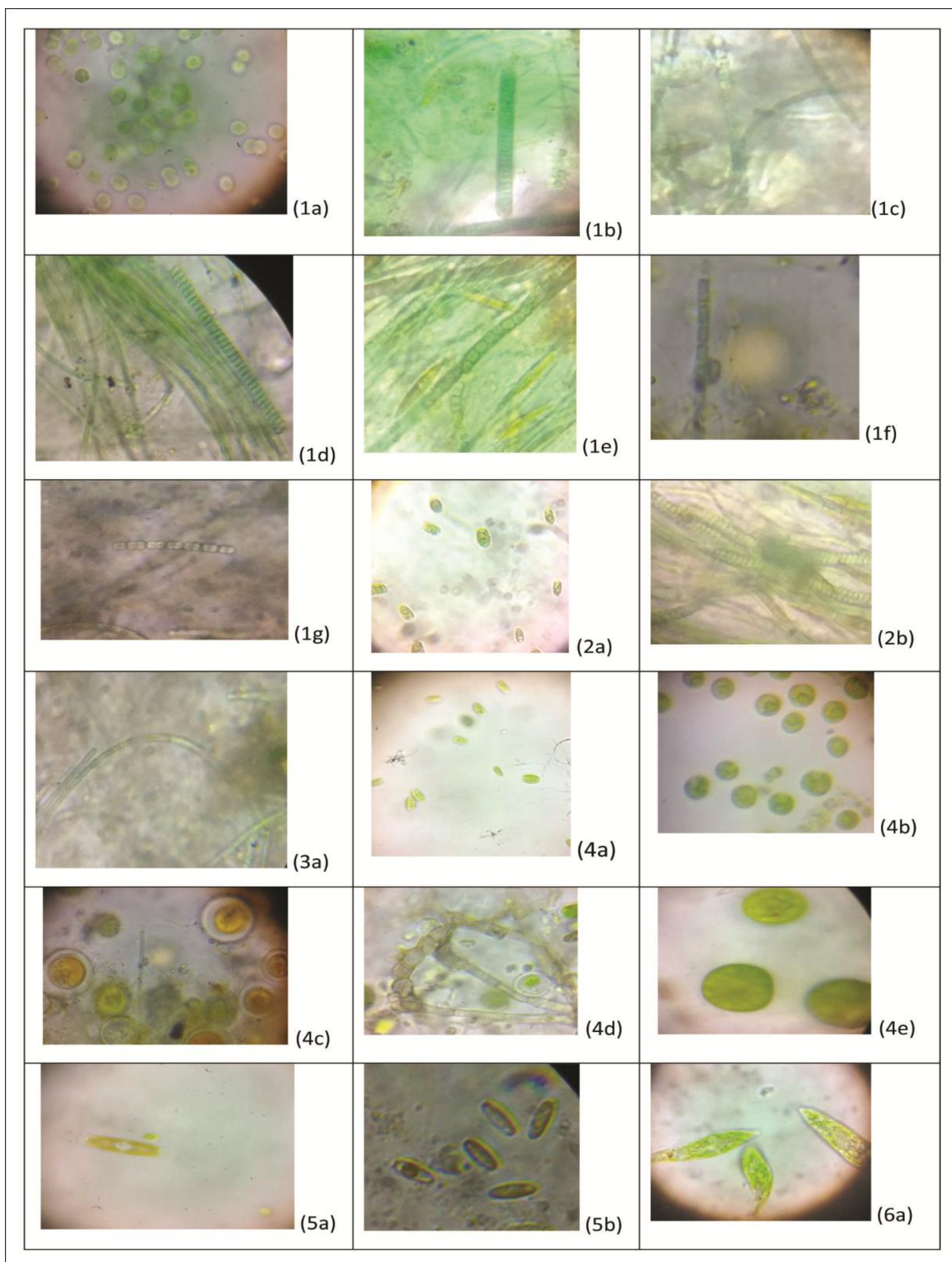


Fig.2 Winogradsky columns prepared with soil samples from different areas

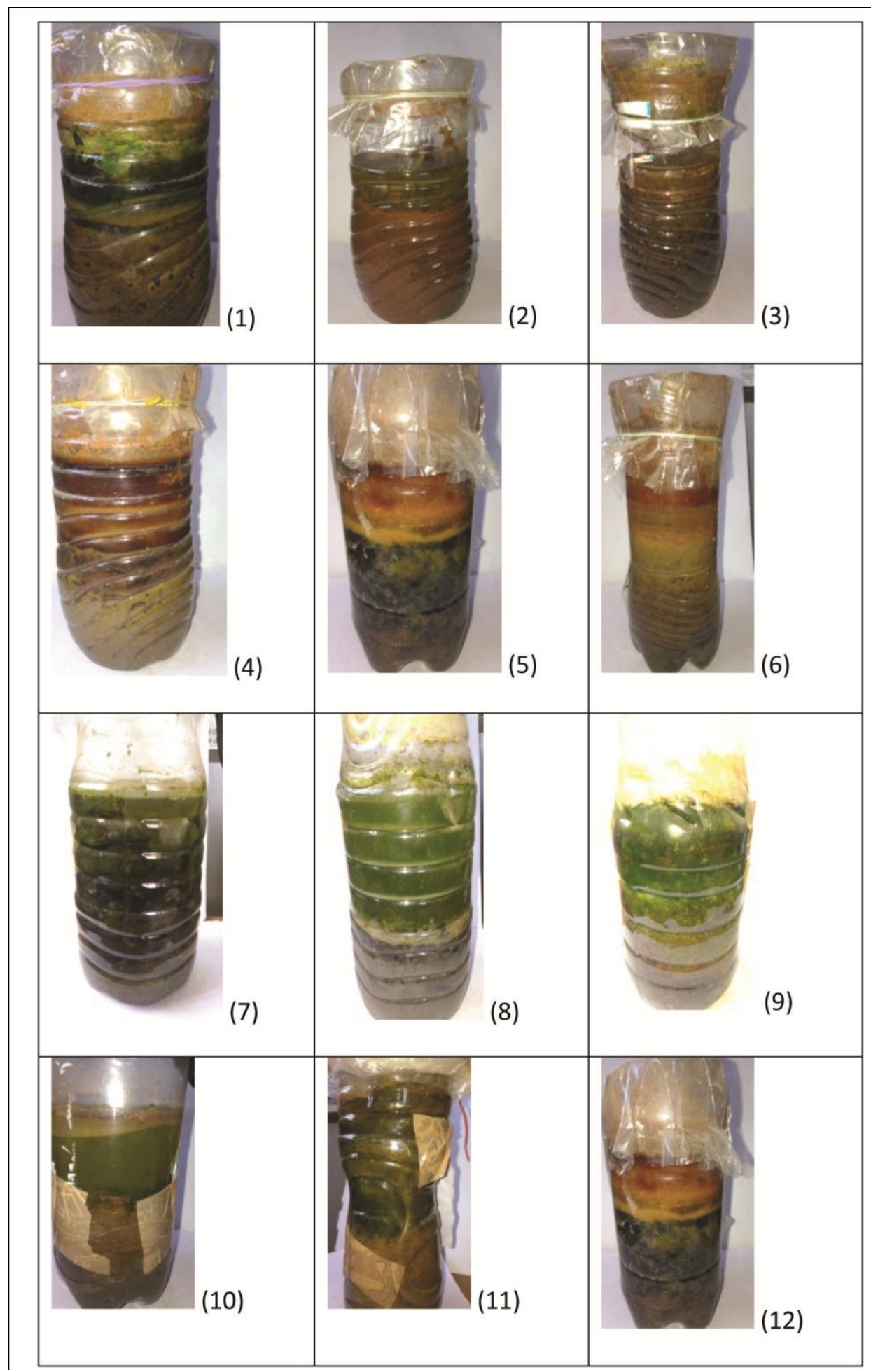

Cells usually connected by extracellular matrix comprising of fibrillar sheath, a tripartite boundary surrounding individual cells, and a fragile gelatinous capsule zone surrounding entire colony. Tripartite boundaries of adjoining cells attached or 
fused with one another; cells more or less spherical to slightly ovoid or pyriform; two equal flagella; cup-shaped chloroplast, with anterior eyespot and 1or 2 pyrenoids; 2 contractile vacuoles.

\section{Pinnularia}

Domain: Eukaryota

Phylum: Heterokontophyta

Class: Bacillariophyceae

Order: Naviculales

Family: Pinnulariaceae

Genus: Pinnularia

It is unicellular, elongated cell. Cell wall is composed of pectic substances. It is covered by mucilaginous layer. Cytoplasm is arranged in parietal layer. A large central vacuole with a single nucleus is present. The most prominent features are the two chloroplasts present along the two sides of the cells. They contain chlorophyll a, c, betacarotene and diatomin or fucoxanthin pigment. Fucoxanthin gives the alga characteristic color. One or two pyrenoids are present in the chloroplast. Their storage compound is oil or chrysolaminarin.

\section{Navicula}

Kingdom: Chromista

Phylum: Ochrophyta

Class: Bacillariophyceae

Order: Naviculales

Family: Naviculaceae

Genus: Navicula

It is commonly known as diatoms and is commonly found in fresh water, water, in air or on soil. Thallus is unicellular, uninucleate and diploid with radial or bilateral symmetry. Cell wall is silicified. They are also known as golden brown algae because of their characteristic pigments like carotenoids, fucoxanthin, diatomin (diatoxanthin, diadinoxanthin). Oil and volutin chrysolaminarin are in the form of stored food products. It shows gliding movement. Reproduction occurs by cell division and auxospore formation. Motile stages possess a single, anterior pantonematic flagellum.

\section{Euglena}

Division: Eukaryota

Class: Euglenoidea

Order: Euglenales

Family: Euglenaceae

Genus: Euglena

They are mostly found in freshwater habitats. Under the microscope they appear as motile typically spindle-shaped and unicellular. They have disc-like chloroplasts which may be pigmented structures within the cell.

In conclusion, taxonomic investigations on algal flora of Assam are generally carried out in ponds, rice fields and ditches. The study with Winogradsky column offers convenient sample development from desired locations with help of soil and water (Fig. 2). The above study resulted in identification of several algae from Panikhaiti area. Further studies on the industrial potential and environmental applications of these algal strains can be carried out.

\section{Acknowledgement}

Authors would like to acknowledge the support rendered by Assam down town University for conducting the above work.

\section{References}

Baruah, P.P., Kakati, B., and Kakati, I.A. 2009. Some Fresh Water Algae of Oil Refinery Effluent Drains of Assam, India. Our Nature, 7: 139-145. 
Deka, M., and Bordoloi, R.P.M. 1991. Studies on the Blue-Green Algae from Rice Field of Assam. Phykos, 30: 175-180.

Harshil, H.B., Sharma, B.M., and Upasani, V.N. 2016. Studies on Microbial Diversity of a Soda Lake in India by Winogradsky Column Technique. Int. J. Curr. Microbiol. Appl. Sci., 5(4): 608614.

Hazarika, D., and Barukial, J. 2012. Occurrence and Distribution of Blue Green Algae in paddy fields of Golaghat district, Assam India. Adv. Plant Sci., 25(1): 341-345.

Jena, M., Ratha, S.K., and Adhikary, S.P. 2005. Algal diversity changes in
Kathajodi River after receiving sewage of Cuttack and its ecological implications. Indian Hydrobiol., 8(1): 67-74.

Sinha, J.P., and Mukherjee, D. 1975. On bluegreen algae from the paddy fields of Bankura District of West Bengal. Phykos, 14: 117-118.

Syiem, M., Nongbri, B.B., Pinokiyo, A., Bhattacharjee, A., Nongrum, N.A., and Hynniewta, L. 2010. Significance of cyanobacterial diversity in different ecological conditions of Meghalaya, India. J. Appl. Natural Sci., 2(1): 134139.

\section{How to cite this article:}

Sushma Gurumayum and Sushree Sangita Senapati. 2017. Exploration of Algal Varieties from Panikhaiti Area of Guwahati using Winogradsky Column. Int.J.Curr.Microbiol.App.Sci. 6(3): 1195-1204. doi: https://doi.org/10.20546/ijcmas.2017.603.139 